\title{
営農型 PV の実情と耐風設計上の課題 \\ Current Status and Issues of the Wind Resistant Design for the Farming PV Systems
}

相原知子 $* 1$

Tomoko AIHARA
染川大輔*2

Daisuke SOMEKAWA
大竹和夫*3

Kazuo OHTAKE
高森浩治*4

Koji TAKAMORI
1.はじめに

2012 年に FIT 制度（固定価格買取制度）が開始された ことにより, 農業の経営 (営農) を行いながら農地の上部 空間に太陽光発電システム (PVS) を設置し, 太陽光を農 業と発電とで共有する営農型 PVS の導入が進んでいる。 営農型 PVS の一例を写真 1 に示す。営農型 PVS は農地 を利用するため, 農林水産省の管轄であり, HPにて「営
農型太陽光発電について」1)や「営農型太陽光発電取組支 援ガイドブック」2)などを公開している。

営農型PVS の設置には，農地法に基づく一時転用の許 可が必要であり，PVS の支柱の基礎部分についても一時 転用許可の対象となる。文献 1)によれば，営農型PVS を 設置するための農地転用許可の実績は，2017 年度までに 1,905 件（再許可を含む）に上る。2018 年 5 月に農地転用
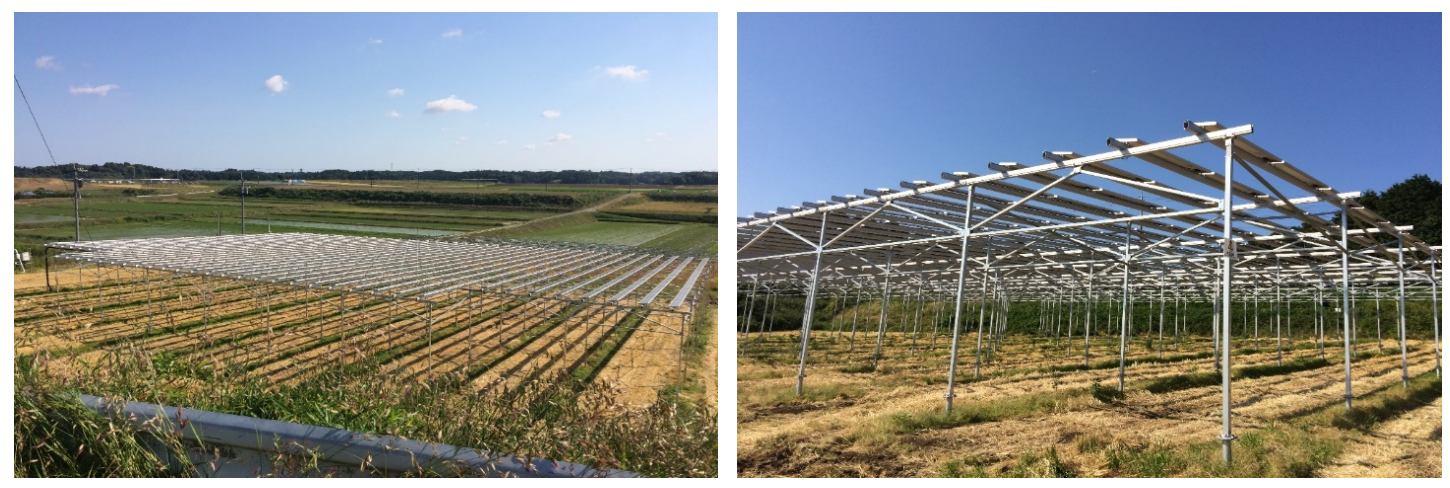

写真 1 営農型 PVS の一例（引用元 : 構造而力評価機構撮影）

\footnotetext{
* 1 大成建設株式会社 技術センター 都市基盤技術研究部 tomoko.aihara@sakura.taisei.co.jp Urban Engineering Research Department, Technology Center, TAISEI CORPORATION

* 2 株式会社大林組 技術研究所 都市環境技術研究部 Urban Environmental Engineering Department, Technical Research Inst. Obayashi Corp.

* 3 株式会社竹中工務店 技術研究所 自然・生態環境部

Natural \& Biological Environmental Engineering Department, Research Development Institute, Takenaka Corporation

* 4 構造耐力評価機構 理事

Director, Structural Performance Evaluation Institute
} 
許可の取り扱いが見直され，担い手が自ら所有する農地 を利用する場合や荒廃農地 (荒廃農地の発生・解消状況に 関する調查要領(平成 20 年 4 月 15 日付け 19 農振第 2125 号農林水産省農村振興局長通知）の 2 亿規定する荒廃農 地）を再生利用寸る場合等において, 一時転用許可期間が 3 年以内から 10 年以内に延長されたことから，更なる導 入の増加が予想される。

「支柱を立てて営農を継続する太陽光発電設備等につ いての農地転用許可制度の取り扱いについて（30 農振第 78 号農林水産省農村振興局長通知)」では, “簡易な構 造で容易に撤去できる支柱として，申請に係る面積が必 要最低限で適正と認められること”, “支柱の高さについ ては, 当該農地の良好な営農条件が維持されるよう, 効率 的な農業機械等の利用が可能な高さ（農業機械による作 業を必要としない場合であっても，農業者が立って農作 業を行うことができる高さ（最低地上高おおむね 2 メー トル以上)）を確保していると認められること”, “下部の 農地における営農が行われない場合又は営農型発電設備 による発電事業が廃止される場合には，支柱を含む当該 設備を速やかに撤去し，農地として利用寸ることができ る状態に回復すること” 等が条件として示されている。

上述したように, 営農型PVS では農作物の品質や収穫 量および作業性を確保するため, 一般的な地上設置型 PVS とは PV モジュールの寸法, 配置間隔, 柱の高さや スパン長等が異なり, 遮光率は低く, 柱は高く, スパンは 長くなる傾向にある。また, 基礎は水田や畑など様々な地 質において強度を発揮し，かつ容易に撤去できるものと しなければならないため, 耐風設計が困難である。

そこで本稿では, 営農型PVS の強風による被害事例の 紹介と而風設計に関する考え方を述べる。

\section{2. 被害事例の紹介}

2019 年 9 月 5 日に発生した台風 15 号は, 9 月 9 日に関 東地方に上陸し，千葉県を中心に甚大な被害を及ぼした。 この台風により被害を受けた営農型 PVS の事例を写真 2 に示寸。写真 2 (a) はPVS の東側端部の状況であり, 架台 の破損とモジュールの飛散がみられる。写真 $2(b)$ に示寸 ように部材接合部 (継手) が破損したことにより架台の倒 壊や変形が発生し，押え金具で固定されていた PV モジ ユールが外れて飛散したものと推定される。写真 2 (c) は, 柱上部と梁の接合部が外れた状況である。アルミ製架台 の部材間接合部には，施工性の観点から $\mathrm{T}$ 溝とスロット による接合が広く用いられているが，溝方向に力が作用 する構造になっているために接合部が外れる事例が少な

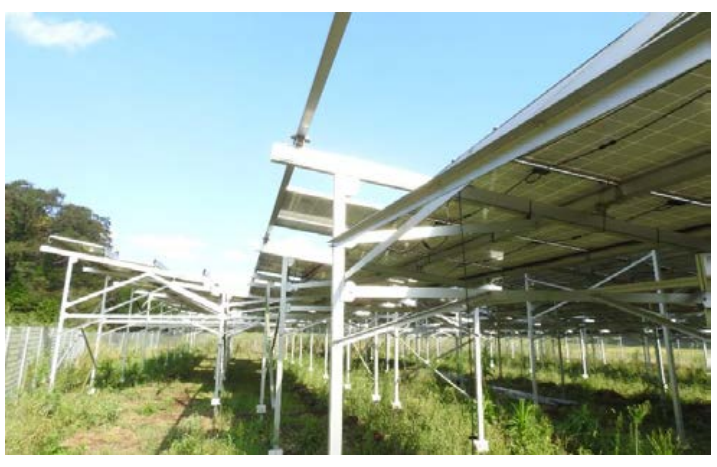

（a）端部での架台の破損とモジュールの飛散

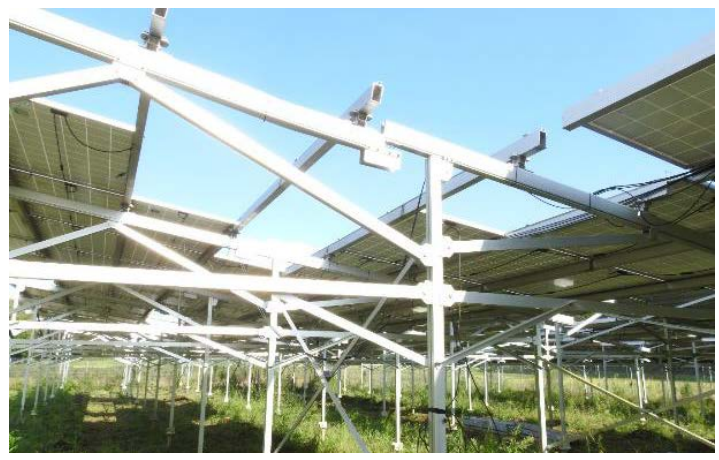

(b) 部材接合部での破損

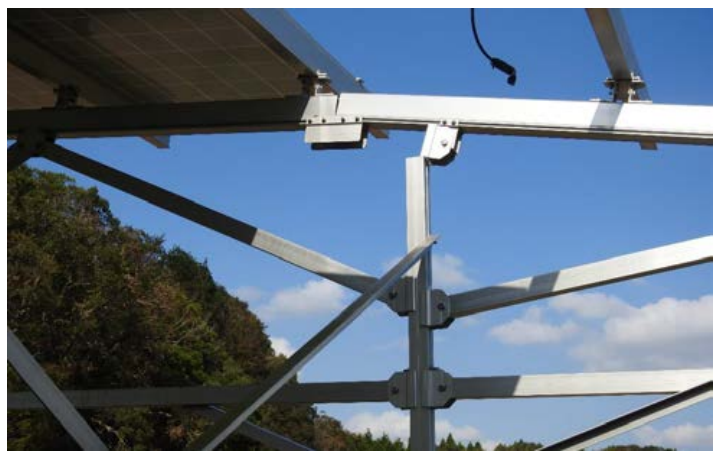

(c) 柱梁接合部材の脱落

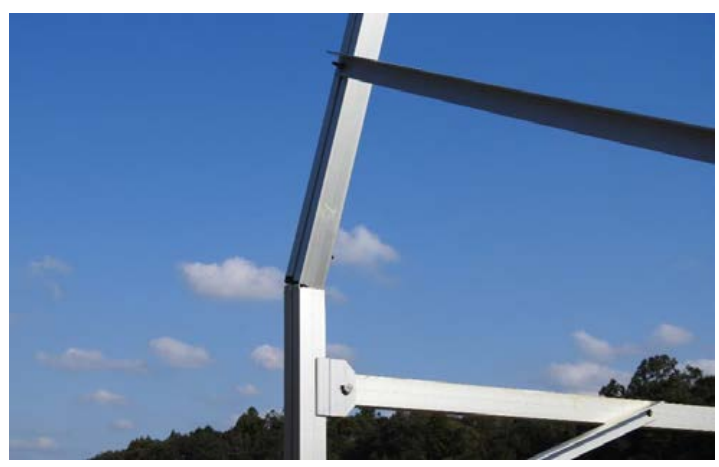

(d) 柱部材の折損

写真 2 強風被害事例

(引用元 : 構造而力評価機構撮影) 
からず発生している。写真 2 (d) は柱部材が中央部で折損 した事例である。アルミ部材は, 熱処理によって強度を向 上させることができるが，部材が脆性的な破壊をする場 合がある。

\section{3. 而風設計の考え方}

\section{1 風荷重の算定方法}

構造骨組用（アレイの支持物設計用）風荷重 $W_{\mathrm{S}}(\mathrm{N})$ お よび外装材用（モジュール設計用）風荷重 $W_{\mathrm{C}}(\mathrm{N})$ は, 次 式で求めることができる ${ }^{3)}$

$$
\begin{aligned}
& W_{\mathrm{S}}=q_{\mathrm{H}} \cdot G_{\mathrm{f}} \cdot C_{\mathrm{f}} \cdot A \\
& W_{\mathrm{C}}=q_{\mathrm{H}} \cdot \hat{C}_{\mathrm{f}} \cdot A
\end{aligned}
$$

ここで,

$q_{\mathrm{H}}:$ 代表高さ $\mathrm{H}$ における平均速度圧 $\left(\mathrm{N} / \mathrm{m}^{2}\right)$

$G_{\mathrm{f}}:$ ガスト影響係数

$C_{\mathrm{f}}$ : アレイ支持物設計用風力係数

$\hat{C}_{\mathrm{f}}:$ モジュール設計用ピーク風力係数

$A:$ 受風面積 $\left(\mathrm{m}^{2}\right)$

なお, JISC 8955 : 20174)に示されている風力係数は, 風 洞実験で得られたアレイのピーク風力係数を JIS C 8955 のガスト影響係数で除した值である。

3. 2 風洞実験の事例紹介

3.1 節に示したように, 風荷重の算定には, 風力係数が
必要であるが, 営農型PV の風力係数はJIS C 8955 に示さ れておらず, 参考となる資料もほとんどない。そこで, 営 農型PVS を対象とした風圧実験と空力実験の概要と結果 を以下に示す。

使用した風洞は (株) 大林組技術研究所所有の多目的大 型風洞実験装置である。風洞実験は風圧実験と空力実験 共に縮尺 $1 / 50$ の模型を用いて行っている。想定した PVS の概要を表 1 に, 平面図と立面図を図 1 に示寸。なお, 一般的な営農型 PV のモジュールの角度は 5 度〜30 度程 度であり, 本害験では 30 度である。

実験風向は, 5 度ピッチとし, 風圧実験は 0 度から 355 度までの 72 風向, 空力実験は模型の対称性を考慮して 0 度から 180 度までの 37 風向である (図 2 参照)。実験気
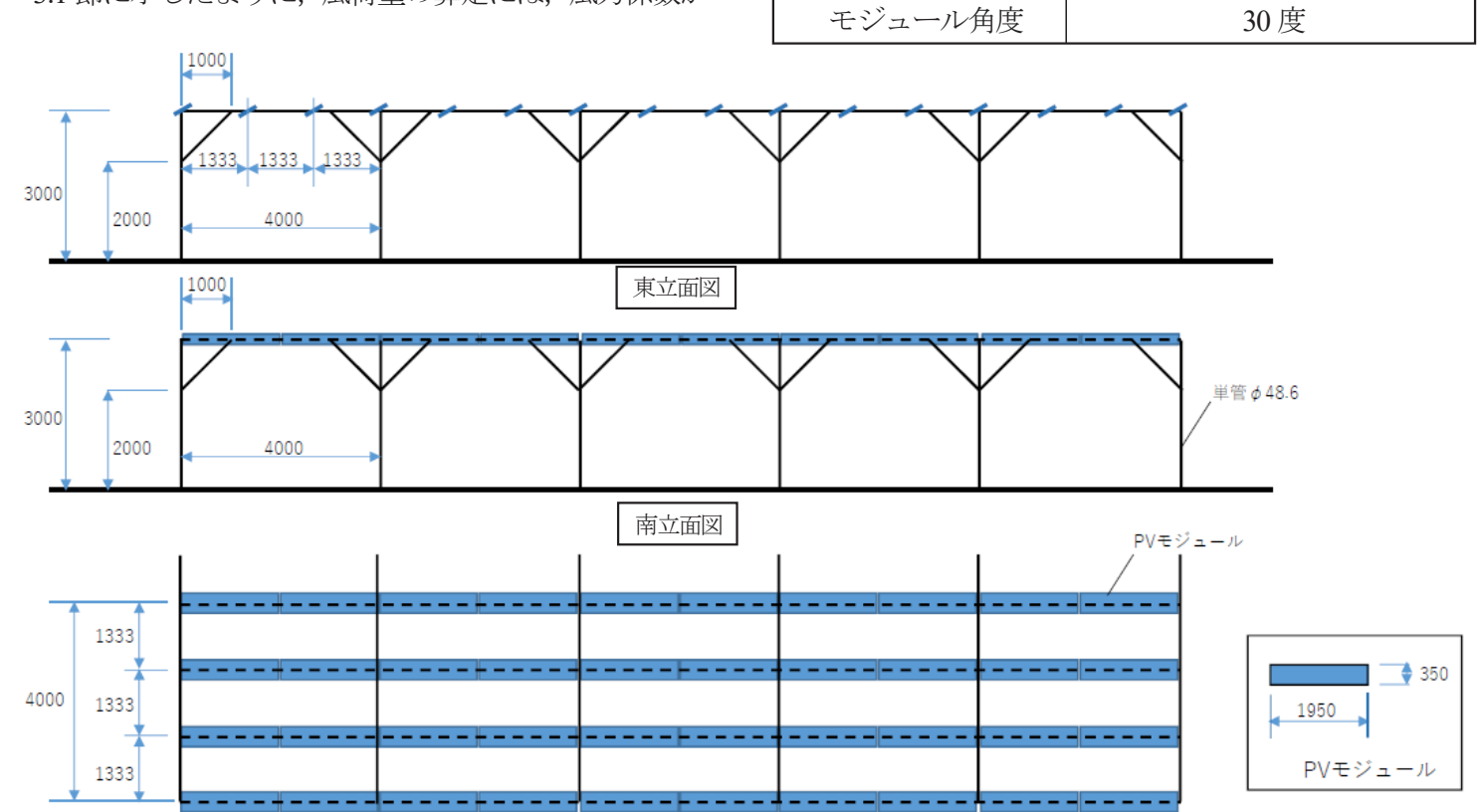

平面図

(単位 : mm)

図 1 想定したPVS の平面図および立面図 
流は建築物荷重指針 5)の地表面粗度区分 II 想定した気 流である。代表高さ（対象構造物の最高高さ3m）におけ る風速は風圧実験で約 $10 \mathrm{~m} / \mathrm{s}$, 空力実験で約 $14 \mathrm{~m} / \mathrm{s}$ であ り, 乱れの強さは 0.26 である。サンプリング周波数とサ ンプリング個数は風圧実験で $1000 \mathrm{~Hz}$ と 180,000 個であ り, 空力実験で $500 \mathrm{~Hz}$ と 30,000 個としている。対象構造 物の設計風速は $30 \mathrm{~m} / \mathrm{s}$ を想定している。

風圧実験で得られた風圧は, 代表高さでの速度圧 $q_{\mathrm{H}}$ を 用いて無次元化し, 風圧係数としている。ピーク值につい ては実時間 0.2 秒相当の移動平均をかけたものと, 平均化 処理を行っていないものの 2 種類を用い, 10 分間相当の ピーク值の 5 組のアンサンブル平均によって評価したも のである。風力係数は, PV モジュール表面の風圧係数と 裏面の風圧係数の差 (時刻歷) から求めており, 下向きが 正である。

風圧実験で得られた PV モジュールに作用する風力係 数の全風向中の最大值と最小值 (ピーク風力係数) を図 3 に示す。移動平均にかかわらず最大・最小共に外周に近い 部分での絶対值が大きい結果となった。最大值では南側 2 段程度の絶対值が大きく, 移動平均なしでは 3.1, 0.2 秒 の移動平均では 2.5 となった。最小值では北側 2 段の絶 対值大きく, 移動平均なしで一 $4.5,0.2$ 秒の移動平均では -3.2であった。また, 中央部付近のアレイでは外周部に 比べ, 6〜7 割程度の風力係数となっており, 風力係数を 低減できる可能性はあると考えられる。

$\mathrm{PV}$ モジュールに作用する風力係数を面積平均して求 めた PV アレイに作用するピーク風力係数のうち, 全風 向中・全アレイの中で最大・最小となったのは, 移動平均 なしで 1.3 と $-1.9,0.2$ 秒の移動平均で 0.96 と -1.5 であ った。この $\mathrm{PV}$ アレイに作用するピーク風力係数の最小 值は JIS C 8955 に示されたアレイ面の風力係数にガスト 影響係数を乗じた值（ガス卜影響係数を 2.1 とした場合: -3.9）と比較して，1/2 程度であった。

空力実験によって得られた構造物基部での水平 2 方向 (南北方向 : X方向，東西方向 : $\mathrm{Y}$ 方向) と鉛直方向 ( 方向, 上向き正）の風力 $F_{\mathrm{X}}, F_{\mathrm{Y}}, F_{\mathrm{Z}}$ およひ転倒モーメント $M_{\mathrm{X}}, M_{\mathrm{Y}}$ は, 次式により構造物全体の風力係数（全体風力 係数) $C_{\mathrm{FX}}, C_{\mathrm{FY}}, C_{\mathrm{FZ}}$ および転倒モーメント係数 $C_{\mathrm{MX}}, C_{\mathrm{MY}}$ と して評価している。

$$
\begin{aligned}
& C_{\mathrm{FX}}=F_{\mathrm{X}} / q_{\mathrm{H}} A_{\mathrm{X}} \\
& C_{\mathrm{FY}}=F_{\mathrm{Y}} / q_{\mathrm{H}} A_{\mathrm{X}} \\
& C_{\mathrm{FZ}}=F_{\mathrm{Z}} / q_{\mathrm{H}} A_{\mathrm{X}} \\
& C_{\mathrm{MX}}=M_{\mathrm{X}} / q_{\mathrm{H}} A_{\mathrm{X}} H
\end{aligned}
$$

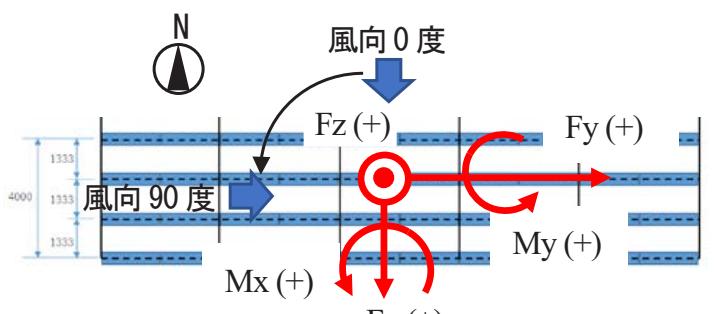

Fx (+)

図 2 風向と力の定義

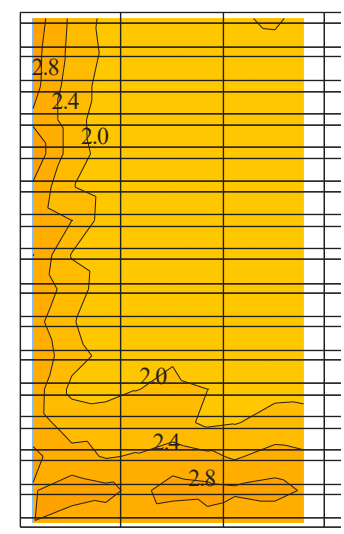

(a) 移動平均なし・最大

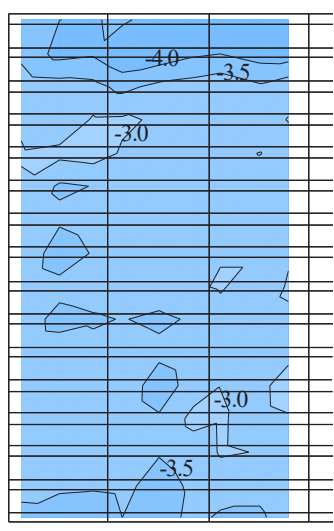

(c) 移動平均なし・最小

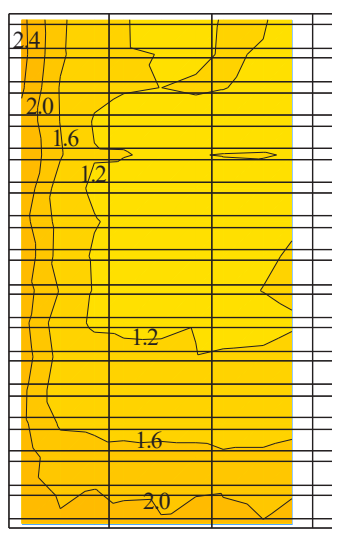

(b) 移動平均 0.2 秒 $\cdot$ 最大

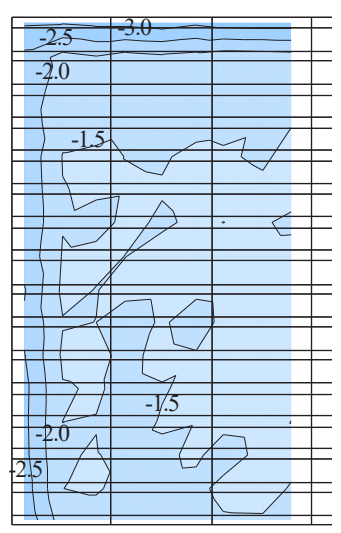

(d) 移動平均 0.2 秒・最小
図 3 全風向中のピーク風力係数（モジュール）

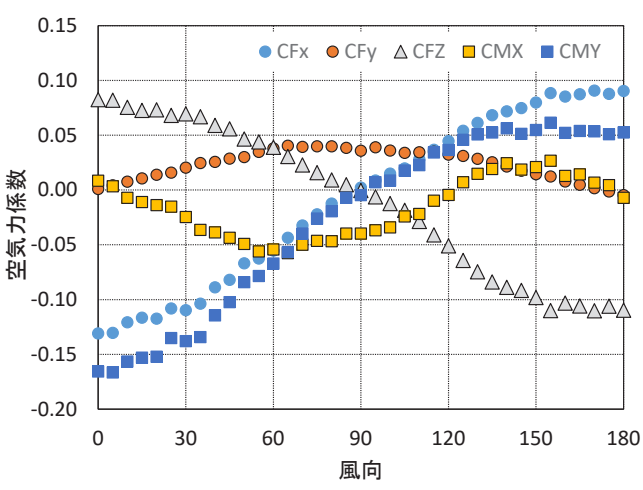

図 4 基部での全体風力係数と転倒モーメント係数 


$$
C_{\mathrm{MY}}=M_{\mathrm{Y}} / q_{\mathrm{H}} A_{\mathrm{X}} H
$$

ここで,

$C_{\mathrm{FX}}, C_{\mathrm{FY}}, C_{\mathrm{FZ}}$ : 基部での各方向の全体風力係数

$C_{\mathrm{MX}}, C_{\mathrm{MY}}$ : 基部での各方向の転倒モーメント係数

$F_{\mathrm{X}}, F_{\mathrm{Y}}, F_{\mathrm{Z}}:$ : 実験で得られた各方向の風力 $(\mathrm{N})$

$M_{\mathrm{X}}, M_{\mathrm{Y}} \quad$ : 実験で得られた各方向の

転倒モーメント $(\mathrm{Nm})$

$A_{\mathrm{X}} \quad$ : 実験模型の代表面積 $\left(=0.025195 \mathrm{~m}^{2}\right)$

$H$ : 実験模型の最高高さ $(=0.06 \mathrm{~m})$

$q_{\mathrm{H}} \quad$ : 高さ $H$ における基準速度圧 $\left(\mathrm{N} / \mathrm{m}^{2}\right)$

なお， $A_{\mathrm{X}}$ は南北方向の真横からみた投影面積であり， 風向と力の方向の定義は図 2 に示すとおりである。

空力実験で得られた基部での全体風力係数と転倒モ一 メント係数を図 4 に示す。全体風力係数は, 南北方向 $(\mathrm{X}$ 方向）の方が東西方向（Y 方向）より絶対值が大きく, 一 0.17 となり, Z 方向では絶対值最大で一 0.11 であった。ま た， $C_{\mathrm{Mx}}$ は南西の風向に相当する $120 \sim 180$ 度付近で負の 值とはなっておらず, そのため 90 度に対して対称な分布 にはならない。これは風上 (南側)の一部分に対してだけ 強い正圧が生じるためであると考えられる。

なお, 本稿で示した営農型PVS のピーク風力係数およ び基部での全体風力係数等は，あくまでも表 1 に示した PVS を対象とした実験結果であり, 全ての営農型PVS に 用いることができる值ではないことに留意されたい。

\section{3 設計用速度圧 (風速) の再現期間の考え方}

JIS C 8955 では，一般的な PVS の設計速度圧を再現期 間 50 年の速度圧として与えている。しかし, 営農型PVS の架台は容易に撤去できるものでなければならない。そ れを理由に風荷重を低減しても良いということにはなら ないが，営農型PVS と比較的条件（地質や周辺環境）が 近い畜舎では, 特定畜舎等建築物の種類により設計風速 の低減率が定められている。畜舎設計基準6では,「滞在 強度（人・時間）／(50 $\mathrm{m}^{2}$ ・年 $) 」$ という概念により, 施 設区分を I の a (乳牛舎, 肉牛舎, 豚舎など), I のb (堆 肥舎, 堆肥舎の付属室), II (搾乳舎, 生乳処理室など), III (施設区分 I およびII 以外) の 4 つに分け, 施設区分に 応じた換算係数（風速の低減率） $R_{\mathrm{W}}$ を設けている。この 換算係数を, 風速の再現期間に換算すると, I の a から順 に, 20 年, 12 年, 30 年, 50 年に相当する。国土交通省 告示第 474 号 7)に示されている風圧力の低減率について も，同様に風速の再現期間に換算すると堆肥舎は 12 年, 飼養施設では 20 年, 搾乳施設等では 30 年である。
畜舎設計基準によると,イギリス (BS-5502,Part22. 1993 年) では, 滞在強度だけでなく, 道路または住居までの最 小距離によって農業建築物を 4 つに分類しており, クラ スに応じた設計荷重の低減がなされている。最小距離が $30 \mathrm{~m}$ の場合は最小設計年数を 2 年, $20 \mathrm{~m}$ の場合は 10 年, $10 \mathrm{~m}$ の場合は 20 年, 限定なしの場合は 50 年としている。

営農型PVSにおいても, 滞在強度や道路または住居ま での最小距離によって風荷重を低減することも考えられ るが, そのためには, 営農における滞在強度の調査や, ア レイの飛散距離に関する調査が必要である。アレイの飛 散距離については，平板を対象とした飛散範囲や飛散物 の軌道に関する研究成果 ${ }^{8)}$, 9)を参考にすることも可能と 考える。ただし, 架台からはずれたアレイの飛散距離の設 定にあたっては，着地後の挙動も考慮する必要がある。

\section{4.まとめ}

本稿では，営農型PVS の特徵をあげ，強風被害の事例 を示した。また, 営農型 PVを対象とした風洞実験（風圧 実験および空力実験）で得られた PV モジュールおよび アレイの風力係数の一例を示した。

謝辞

本稿には国立研究開発法人 新エネルギー・産業技術総 合開発機構 (NEDO) の委託研究「太陽光発電システム長 期安定電源化基盤技術開発プロジェクト」の成果の一部 が含まれております。

参考文献

1）農林水産省食料産業局バイオマス循環資源課再生可 能エネルギ一室，「営農型太陽光発電について」，

https://www.maff.go.jp/j/shokusan/renewable/energy/attac h/pdf/einou-30.pdf, (2020.1)

2) 農林水産省，「営農型太陽光発電取組支援ガイドブッ ク（2018 年度版)」，

https://www.maff.go.jp/j/shokusan/renewable/energy/attac h/pdf/einou-26.pdf, (2020.1)

3）日本風工学会,「太陽光発電システム耐風設計マニュ アル」, (2017.2)

4）日本規格協会，「JIS C 8955 太陽電池アレイ支持物の 設計用風荷重算出法」,(2017)

5）日本建築学会，「建築物荷重指針・同解説 2015」, (2015)

6) 社団法人日本畜産施設機械協会, 建築大臣認定「畜舎 設計基準・同解説」,(2000.8) 
7) 平成 14 年国土交通省告示第 474 号，「特定畜舎等建 築物の構造方法に関する安全上必要な技術的基準を 定める件」, (2002.5)

8）立川正夫，「飛散物の飛散範囲の推定方法 台風時の 飛散物の軌跡と速度に関する研究 その $5 」$, 日本建
築学会構造系論文報告集, 第363 号,pp.42-49,(1986.5)

9) J. D. Holmes, C. W. Letchford, Ning Lin, "Investigations of plate-type windborne debris -part II: Computed trajectories", Journal of Wind Engineering and Industrial Aerodynamics 94, pp.21-39, (2006) 